\title{
A feedback loop between human self-domestication and dog domestication contributing to language evolution?
}

\author{
Antonio Benítez-Burraco ${ }^{\mathrm{a}}$, Daniela Pörtl ${ }^{\mathrm{b}}$, and Christoph Jung ${ }^{\mathrm{c}}$ \\ a. Department of Spanish Language, Linguistics and Literary Theory (Linguistics), \\ Faculty of Philology, University of Seville, Spain \\ b. Psychiatric Department, Saale-Unstrut Klinikum, Teaching Hospital Leipzig and Jena \\ Universities, Naumburg, Germany \\ c. Petwatch, Halle, Germany
}

\begin{abstract}
Different factors seemingly account for the emergence of present-day languages in our species. Human self-domestication has been recently invoked as one important force favouring language complexity mostly via a cultural mechanism. As a consequence, evolutionary changes impacting on aggression levels are expected to have fostered this process. Here we hypothesise about a positive effect of dog-human interactions on aggression management and more generally, on our self-domestication, ultimately, contributing to aspects of language evolution. We review evidence of diverse sort (ethological mostly, but also archaeological, genetic, and physiological) supporting a positive feedback loop between dog domestication and human-self domestication that might have favoured the mechanisms promoting structural complexity in human languages.
\end{abstract}

Keywords: dog domestication; human self-domestication; aggression; prosociality; language evolution; cognitive disorders 


\section{Introduction}

During the last decades, language evolution has emerged as a favourite topic of inquiry for researchers of different persuasion, from linguists to anthropologists to ethologists to prehistorians. Language is a hallmark of the human distinctive phenotype, enabling sophisticated ways of thinking, communicating information, and organizing human societies. For many years, a sharp divide was stablished between the evolution of the cognitive and behavioural hardware that enables us to learn and use languages (aka faculty of language, language-ready-brain, or more recently, human linguisticality) and the particular codes we use in our daily interactions (aka languages). Whereas the former has been hypothesized to result from biological changes mostly (aka language evolution), present-day languages have been hypothesized to derive from the first language(s) used by first anatomically-modern humans (AMHs) via random modifications triggered by external factors, like isolation or cultural exchanges (aka language change). Putting this differently, although many languages are currently spoken by human beings, they have been thought to exhibit similar core properties because these properties are imposed by our brain architecture. Increasing evidence (reviewed e.g. by Benítez-Burraco, 2019) suggests instead that our behavioural and cognitive hardware might have gone on evolving after our inception. For instance, our characteristic globular skull/brain, which is hypothesized to account for some of our distinctive cognitive abilities, can be only attested in recent specimens of AMHs (Neubauer et al., 2018). Likewise, several genes involved in brain development and function show signals of positive selection well after our split from extinct hominins (Zhou et al., 2017). Our behaviour has equally changed with time, with evidence of modern behaviour and culture being widespread only from 100-50 thousands years ago (kya) onwards (McBrearty and Brooks, 2000; Mellars, 2002). 
On a different note, languages have been shown to be constrained by (or even adapt to) environmental factors, mostly cultural, but physical too, with some core properties of human language (like duality of pattern) emerging via a cultural process as languages are learned and transmitted by speakers (Sandler et al., 2005; Lupyan and Dale, 2010). Ultimately, increasing evidence supports as well the view that the different languages we learn and use have a differential impact on selected cognitive abilities, like working memory (e.g. Amici et al., 2019), and eventually on our cognitive architecture, particularly if cognitive gadgets aimed to process them more quickly and efficiently are implemented (e.g. Clarke and Heyes, 2017). All this evidence suggests that better than the outcome of a lineal evolutionary process (with language evolution occurring first and language change happening later), the emergence of modern languages should be instead viewed as an (ongoing) feedback loop between our biological endowment and our cultural practices.

In biological sciences, niche construction theory has recently emerged as a robust theory aimed to account for this feedback loop and eventually, for most aspects of human evolution. Under this view, our biology enables us to construct a cultural environment or niche (encompassing ways of life in a broad sense, from clothe making to food supplies strategies to transmission of know-hows) that modifies, reduces, or even eliminates many of the selective pressures most animals need to cope with and which they address via biological change. Certainly, many other animal species exhibit some form of culture that increases their survival rates without implying biological modifications, but in our species cultural niche construction is widespread and seemingly accounts from many crucial aspects of our distinctive phenotype (Laland et al., 2000; Kobayashi et al., 2019), including language (Sinha, 2015). 
The domestic environment also results in a relaxation of selective pressures and can be construed as well as a sort of niche. Interestingly, domestication has been claimed to trigger some common features in mammals: this is the so-called "domestication syndrome" (Wilkins et al., 2014). Although it is disputed that this syndrome is a universal outcome of domestication processes, some common changes in behaviour (like increased tameness) and in cognitive abilities (like enhanced social learning) via changes in the brain (like a reduction in brain size) are usually observed in most domesticated animals (see Sánchez-Villagra, et al. 2016 for discussion). Interestingly, when compared to extant apes and extinct hominins, humans exhibit many of the traits found in domesticates (see Shea, 1989; Leach, 2003; Somel et al., 2009; Zollikofer and Ponce de León, 2010; Herrmann et al., 2011; Plavcan, 2012; Stringer, 2016; Hare, 2017 for different features), hence the claim that we were engaged in some sort of domestication process too. This is the hypothesis of human self-domestication, which can be thus viewed as a sort of niche construction, according to which our domestication accounts for most aspects of our complex social and cultural practices, including our notable cooperation, our improved social cognition, the widespread social networks we form (also encompassing non-kin people), and our sophisticated technology (Hare, 2017). Interestingly too, in songbird species, domestication increases song complexity (Takahashi and Okanoya, 2010; Kagawa et al., 2014; Okanoya, 2017). This finding paved the way towards claims that domestication might be involved in the evolution of human language too. Although a comprehensive model of language evolution under the effects of self-domestication is still pending, some hints can be found in the recent literature. For instance, Thomas and Kirby (2018) has argued that our self-domestication brought about the processes that enable the cultural evolution of language, particularly, the transmission of communicative 
systems through learning, as well as the ability to infer the communicative intent associated with a signal or action. Likewise, in a series of related papers, Benítez-Burraco and Progovac (Progovac and Benítez-Burraco, 2019; Benítez-Burraco and Progovac, in press; Benítez-Burraco and Progovac, submitted) have explored in detail how changes in the management of aggression as a result of our increased self-domestication might have contributed to make languages more complex over time via its impact on behaviors needed for acquiring and mastering them (like language learning by children, language teaching by adults, or language play), with self-domestication and language complexity being engaged in a positive feedback loop.

Hypotheses of this sort are difficult to test, as languages leave no trace in the fossil or the archaeological records. For testing them, we need to rely on proxies or windows to previous stages in the evolution of language (and of languages), provided that the proper bridging inferences can be postulated. One useful proxy of this sort are animal models. One important conclusion of recent comparative approaches to the evolution of human language is that its basic building blocks are shared with other animals (although some human-specific innovations can be expected too). Likewise, as discussed above, it seems that humans and some animal species have been involved in a process of (selfdomestication, with some common phenotypical features resulting for this process. Accordingly, the aim of this paper is twofold. On the one hand, we wish to explore the putative role of dog domestication as a model of the changes happened in human cognition and behaviour under the effect of self-domestication, with a focus on our communicative abilities, particularly language. Several lines of evidence support this approach. First, contrary to other species, dogs exhibit most of the distinctive features encompassing the "domestication syndrome” (Sánchez-Villagra et al, 2016). Second, as 
we discuss in detail in the next section, dog domestication resulted from selection for tameness, pretty much like human self-domestication did. Third, in dogs, domestication results in the enhancement of cognitive abilities and behaviours that are crucial for language acquisition and use, like the sensibility to social cues and the ability to solve problems relying on social cues (Hernádi et al. 2012, Udell, 2015). Finally, common genetic determinants might account for the enhanced sociability associated to (self)domestication in both dogs and humans. Hence, genes selected in dogs overlap with genes selected in AMHs (Theofanopoulou et al., 2017). More importantly, some chromosomal regions known to be under positive selection in dogs are associated with aspects of our distinctive social behaviour, as it is the case with the region deleted in Williams syndrome (WS) (VonHoldt et al., 2017). The fact that people with WS exhibit exacerbated features of human self-domestication (Niego and Benítez-Burraco, 2019) makes this connection more intriguing.

Nonetheless, the paper is also aimed to explore the more controversial possibility that human self-domestication and dog domestication were engaged in some sort of positive feedback loop and that this mutual reinforcement contributed to language evolution in some subtle, but still important ways. Again, several lines of evidence seemingly support this possibility. First, dog domestication started around 45 kya, a period when features of human self-domestication reached its peak (Cieri et al., 2014). Second, closely living and working together with a different species have been shown to reduce stress and therefore the activity of hypothalamic-pituitary-adrenal (HPA) axis, this circumstance usually resulting in enhanced sociability, or even hypersociability, ultimately favouring all the changes associated to (self-)domestication (Jung and Pörtl, 2015). Third, and related to this, dog domestication made human social networks larger and more complex by 
including members of other species, this circumstance seemingly demanding enhanced tolerance to non-kin as well as extra emotional bonding and perhaps improved mindreading too. Contacts with non-kin and ultimately, the establishment of intergroup social networks (but also the management of intergroup conflicts) have been hypothesized to account for specific types of human languages (see Benítez-Burraco and Progovac, in press for details), as well as for the emergence of modern use of languages, that is, modern pragmatics (Benitez-Burraco and Progovac, submitted).

The paper is structured as follows. We first provide a brief characterization of human selfdomestication vis-à-vis dog domestication, highlighting the parallels between the two processes. We then explore the effects of human-dog interactions on their respective behavioural and cognitive phenotypes, with a focus on aspects known to be affected by (self-)domestication. Finally, we focus on communication, both verbal and non-verbal, and advance some conjectures about the putative effects of this coexistence (and possibly, co-evolution) on the emergence of present-day languages.

\section{Human self-domestication and dog domestication vis-a-vis}

As noted, domesticated animals exhibit a set of distinctive features compared to their wild conspecifics. It has been claimed that these traits are shared across domesticates, to the extent that a "domestication syndrome" can be posited (Wilkins et al., 2014). These common features include body differences (floppy ears, shorter snouts, smaller jaws, smaller teeth, reduced skulls/brains, depigmentation), physiological changes (neoteny, shorter reproductive cycles, earlier sexual maturity, increased fecundity, adrenal hypofunction, reduced levels of stress hormones), behavioural differences (increased 
docility), and even cognitive changes (enhanced skilfulness in using human cues). According to Wilkins and colleagues (2014), this common set of features associated to domestication results from the impact of selection for tameness on the neural crest, an embryonic structure involved in the development of multiple body parts.

As discussed by Sánchez-Villagra et al. (2016), not all these features are present in all mammal domesticates, although dogs are a notable exception, as they show the full syndrome. Humans show many of these traits too. Accordingly, compared to extinct hominins, AMHs exhibit reduced skulls/brains (at least during the last $50 \mathrm{ky}$ ), reduced teeth, childish faces, neoteny, and reduced reactive aggressiveness (Márquez et al., 2014; Thomas, 2014; Fukase et al., 2015; Stringer, 2016; Hare, 2017), with the expression of these features of domestication having intensified recently, during Upper Palaeolithic (Cieri et al., 2014). Interestingly enough, candidate genes for mammal domestication are overrepresented among the genes under positive selection in AMHs compared to Neanderthals and Denisovans (Theofanopoulou et al., 2017). What is more, different sets of candidates for animal domestication seem to have been selected at different moments during human evolution, suggesting that human self-domestication is a sequential (and ongoing) process (Benítez-Burraco et al., 2019). As noted, in mammals domestication is usually triggered by selection for tameness. It has been hypothesized that human selfdomestication also resulted from selection of less threatening and less emotionally reactive partners, as a consequence of the advent of community living (particularly, when this involved extra-group individuals), co-parenting, and/or changes in human foraging ecology (Hare et al., 2012; Pisor and Surbeck, 2019). Reduced environmental stress resulting from generalized fire and tool using (Domínguez-Rodrigo and Pickering, 2017) might have contributed as well to our self-domestication, considering the positive effect 
of decreased environmental stress conditions on prosocial behaviour, as seen in bonobos (Hare et al., 2012), island wolves (Darimont et al., 2014), or Florida key deers (Harveson et al., 2007). Finally, it is also well possible that some of the changes that brought about our species also contributed to our self-domesticated phenotype, at least initially, as genes accounting for human-specific traits, particularly our globular skull/brain and our language-readiness, interact with, or are themselves candidates for, mammal domestication (see Benítez-Burraco et al., 2018 for discussion).

Regarding dog domestication, evidence of diverse sort suggests that it might have started about 45-40 kya in Europe and that it might have occurred really quickly. Evidence is mostly paleogenetic evidence (e.g. Thalmann et al., 2013; Botiqué et al., 2017), but also anatomical evidence has been found. Hence, remains of early dogs or protodogs, some of them clearly dated as older as 30 kya, have been excavated in Europe (Germonpré et al., 2009, 2012, 2015; Ovodov et al., 2011; Prassack et al., 2020). About the rationales for dog domestication, man has used dogs as a working force mostly. Even the first dogs seemingly provided general economic services like in hunting, guarding, or travelling (Zhang et al., 2020). It is likely, that dogs adapted the knowhow to hunt big mammals like mammoth from wolves (Schleidt and Shalter 2003, 2018). Overall, this means that dogs have been living closely linked to human for several ten thousand years. Selection for social skills, mainly to improve friendliness and communication in behaviour and appearance, were leading factors in dog domestication and resulted in animals capable of working together with humans in an active form of partnership, developing complex human-analogue social behaviours (Topál et al., 2009; Marshall-Pescini et al., 2012, 2014). 
The first steps towards dog domestication seemingly involved ancient wolves with genetically predisposed friendly behaviour (some wolves are reported to maintain interspecific prosocial contacts e.g. toward ravens, Stahler et al., 2002, or monkeys, Venkataraman et al., 2020) and AMHs starting some sort of basic interspecific prosocial communication, first in all likelihood by the need to avoid risk of injury (Hare, 2017; Kotrschal, 2018). These initial interactions might have also been facilitated by the fact that wolves and humans are both highly social mammals with similar social family structures, including alloparenting and trusting in the prosocial care of the whole family clan (Mech, 1999, 2009; Hawkes, 2003; Page et al., 2017). Similarities extend as well to their refined communication with conspecifics, including complex mimicry (Nagasawa et al., 2011) and joint attention and vocal communication (Mech, 2009; Range and Virány, 2011; Marshall-Pescini et al., 2017). Finally, both AMHs and wolves are equipped with mirror neuron mechanisms, comparable limbic functions and similar basic function of prefrontal inhibition (Rizzolatti, 2004; de Waal, 2005; Oberman et al., 2007; Welberg, 2008; Bartal, 2011; Ferrari, 2016; Kilner and Lemon, 2013), enabling them even interspecific empathy and basic Theory of Mind (ToM) (Catala et al., 2017, Huber et al., 2020). All this seemingly helped starting cooperation leading to a "working together culture" (Avital and Jablonka, 2000; Wayne, 2013; Filatova et al., 2015; Foote et al., 2016; Jung and Pörtl, 2019).

Still, the two species, dogs and wolves, show remarkable behavioural differences despite the relatively recent divergence time. Since dogs and wolves are nearly identical at the level of DNA sequence, differences are expected to result mostly from dissimilar gene expression patterns in selected body regions, notably brain areas (vonHoldt et al., 2010). Accordingly, Axelsson and colleagues (2013) found among the regions with signals of 
positive selection in dogs, nineteen genes important for brain function, with eight of them being involved in development pathways potentially underling behavioural changes central to dog domestication. Likewise, Cagan and Blass (2016) found signals of strong selection during the initial stages of dog domestication on multiple genes involved in the fight-and-flight response, particularly in the catecholamine synthesis pathways contributing to reduced aggression and fear toward humans. One region of particular interest is the hypothalamus. Whereas gene expression patterns in the hypothalamus of wolves and coyotes are very similar, seemingly because of their stable environmental conditions, in dogs a more flexible pattern is observed, seemingly due to fast changing conditions of human environment (Saetre et al., 2004). As noted in the previous section, the hypothalamus, as part of the HPA axis, contributes to regulate stress, aggressiveness, and sociability. Another region of interest is the hippocampus. In tamed foxes, tameness is accompanied by global and region-specific hippocampal increases in neurogenesis due to a lower reactivity of the HPA axis (Huang et al., 2015). The hippocampus is one key component of the neural substrate supporting cognitive maps for navigating physical space, but also social space, including tracking social behaviour and adapting to new social contexts (Montagrin et al., 2018). Domestication has probed to result in enhanced spatial learning and contextual memory (Rehkämper et al., 2008; Lewejohann et al., 2010). Interestingly too, the hippocampus plays an important role as well in language processing (Covington and Duff, 2016; Piai et al., 2016; Kepinska et al., 2018). It is thus tentative to speculate that domestication might have contributed to enhance communication abilities via changes in the hippocampus (more on communication in the next section). 
Finally, one interesting result of dog domestication was the rise of dog breeds, which are populations with a set of highly specified traits developed to fulfil specialized functions in human society (Schoenebeck and Ostrander, 2014; Zhang et al., 2020). A dog breed can be clearly identified by its appearance, behaviour and genetic fingerprint. Interestingly, as recently found by MacLean and colleagues (2019), breed differences in behaviour (including degrees of aggression, fear, trainability, attachment, and predatory chasing behaviours) are highly heritable, to the extent that clustering of breeds based on behaviour accurately recapitulates their genetic relationships. Interestingly too, breed specialization is mirrored in the brain anatomy, which varies significantly between breeds, likely due to human applied selection for behaviour (Hecht et al., 2019; 2020). The most conspicuous alterations in the brains of different lineages of domestic dogs concern to regions managing inhibitory control and communication skills towards humans (more on this on section 4 below). For instance, as noted by Frederik (2019), brain differences in scent dogs concern not to areas involved in smelling, but instead in the more sophisticated areas that help dogs to understand and communicate information.

\section{Human-dog coexistence... and co-domestication?}

It is a long way from the wolf to the first dogs, to specialized dogs and eventually to breeds. Therefore, thousands of years of co-living and co-working. Sled dog teams might have been used in Siberia as early as 15 kya (Pitulko and Kasparov, 2017). The oldest fossilized bones representing two clearly different breeds are 9 ky old: sledding and hunting dogs (Pitulko and Kasparov, 2017). Since the beginnings of the Neolithic period we discover ample evidence for dogs as specialized working partners for hunting, herding, sledding, or guarding on all continents, apart Australia (Jung, 2011; Perri, 2016; 
Guagnin et al., 2018). Cave paintings and rock art from Northern Africa or the Arabian Peninsula from 9-10 kya show man and dog hunting or herding together (Coulson and Campbell, 2001; Holl, 2004; Guagnin et al. 2018). As cultures and technologies developed, jobs carried out by working dogs did so as well, resulting into the separation of dogs in dozens of breeds (Jung and Pörtl, 2018). Overall, human social, economic and cultural evolution is mirrored in the evolution of dog, its specializations and its breeds. Putting this differently, we may understand dog breeds as a reflection of human cultural evolution.

In some instances, we can speak indeed of a real co-evolution. A simple instance is the adaptation of dogs to a starch-rich diet, with the copy number of genes involved in the breakdown of amylase being greater in modern companion breeds than in sledge dogs, reflecting the spread of agriculture during Prehistory (Arendt et al., 2016; Ollivier et al., 2016). Likewise, Tibetan dogs and Tibetan people exhibit similar adaptive strategies for living in the high altitude of Himalayan Mountains (Wang et al., 2014), to the extent that in both cases, positive selection signals have been attested in the same gene, namely EPAS1 (Gou et al., 2014; Li et al., 2014b; Xu et al., 2014). At the same time, dogs are expected to have contributed significantly to changes in human society, of the sort discussed above, resulting in a "working together culture", perhaps eventually establishing a new human culture like mammoth-hunting (Shipman, 2015). As noted, we may address this as a form of coevolution (Schleidt and Shalter, 2003, 2018; Russel, 2018; Jung and Pörtl, 2019) or, in other words, as an (ongoing) feedback loop. Darwin referred to this process as "coadaptation" (1860, p. 31). 
Our main argument in this paper is that we may consider extending this possibility of a co-evolution between dogs and humans to the process of domestication itself, ultimately claiming that both species have been engaged in a co-domestication process. According to this view, dog domestication and specialization of dogs, eventually leading to breeds, can be understood as a reflection of human self-domestication, with its increased prosocial behavior (Jung and Pörtl, 2019), whereas dog domestication may also be construed as an active factor promoting human self-domestication, as it reinforced our trend towards increased prosociality (Jung and Pörtl, 2015, 2018, 2019). More specifically, our hypothesis is that increased interspecific prosocial communication with dogs might have fostered the advent of the changes commonly associated to human selfdomestication, as described in the previous section. The crucial modification would have been the integration of the wolf into the human social structure, which was previously characterized by family based groups with only little permeability, with the only exception of the assimilation of mating partners to avoid inbreeding (Sikora et al., 2017). Elsewhere, we have called this view the hypothesis of "active social domestication" (Jung and Pörtl, 2015; Pörtl and Jung 2017, 2019). Cohabitation and communication with wolves (and later, with dogs) seemingly promoted a further reduction of reactive aggression (to avoid conflicts with a non-kin species) and a further potentiation of aspects of ToM (to avoid misunderstandings and miscommunications with a non-kin species), this enhancing in turn prosocial behaviours and ultimately, resulting in enhanced cognitive capabilities and the other changes associated to human self-domestication.

The view that dog domestication and human self-domestication might have been involved in a positive feedback loop is supported by evidence of diverse nature, from archaeological, to physiological, to genetic. We now review this evidence. In the next 
section we will focus on language abilities, as interspecific communication might have played a key role in triggering and enabling this feedback loop.

First, the advent of dog itself. As noted in the previous section, the onset of dog domestication is proclaimed about 45-40 kya. This is the period when cumulative technological and cultural evolution of AMHs took an enormous leap into a new area of modernity (McBrearty and Brooks, 2000; Mellars, 2002), but also when features of human self-domestication reached its peak (Cieri et al., 2014).

Second, archaeological findings point to a closely living of dogs as in-group members. Specifically, dog burials are frequent during the Palaeolithic period and they are often human-dog graves, like in Oberkassel, Germany, dated 14,2 kya (Morey and Wiant, 1992; Morey, 1994; Losey et al., 2011, 2013; Janssens et al., 2018). This circumstance tells of a deep emotional link between dogs and Palaeolithic people (Janssens et al., 2018; Jung and Pörtl, 2018), particularly, if one considers that in the Oberkassel grave one of the buried dogs had been ill for several months and had received intensive human care before dying (Janssens, 2018). As noted, these intense inter-species contacts are expected to have contributed to reduce reactive aggression in both humans and $\operatorname{dogs}$ and to increase tolerance towards non-kin.

Third, interacting with dogs is known to reduce physiological signals/triggers of stress and reactive aggression in their human handlers, including heart rates, blood pressure and pulse frequencies (e.g. Friedmann et al., 1983; Grossberg and Alf, 1985; Nagenangst et al., 1997; Hansen et al., 1999); cortisol levels (Barker et al., 2005; Beetz et al., 2011), and serotonin and oxytocin release (Odendaal, 2000; Odendaal and Meintjes, 2003; Miller et 
al., 2009; Nagasawa et al., 2009; Handlin et al., 2011; Beetz et al., 2012). Heart activity depends on stress hormones like cortisol and noradrenalin (Kelly et al. 1998; Whitworth et al., 2005; Santana et al., 2017). Cortisol controls fight-and-flight response and ultimately, reactive aggression (van Bokhoven et al., 2005; Böhnke et al., 2010; Montoya et al., 2011). Regarding oxytocin, this is one crucial neuropeptide providing in-group bonding and out-group rejection (Kosfeld et al., 2005; Zhang et al., 2019). In humans, this is one of the hormones hypothesized to have been targeted for sexual selection with respect to a reduction in physically aggressive behaviour in the context of our selfdomestication (Hare, 2017).

Fourth, this close relationship between dogs and humans can impact on key cognitive abilities via brain changes promoted by the physiological mechanisms involved in ingroup affiliation and stress management. Accordingly, decreased cortisol levels have been shown to cause dendritic growth (McEwen and Morrison, 2013), ultimately improving neural structures, like prefrontal cortex, which are crucially involved in social learning and inhibitory control (Arai et al., 2009; Brusini et al., 2018). Compared to wolves, dogs are suggested to possess a higher level of inhibitory control concerning humans that means dogs show less aggressive behaviour even towards foreign people (Marshall-Pescini et al., 2015). Likewise, oxytocin, delivered intranasally, results in dogs in an enhanced ability to perform an object choice task involving the use of human pointing cues (Oliva et al., 2019). Oxytocin also enhances joint attention (Nagasawa et al., 2015) as a link to object learning (Marshall-Piscini et al., 2012; 2014). As noted by Meaney and Szyf (2005), reduced stress levels and enhanced prosocial behaviours can modulate brain function epigenetically. Overall, reduced individual stress activity within a mixed human-wolves clans might be hypothesized to have had an evolutionary benefit. 
Thus, from generation to generation cortisol sensitivity might have decreased more and more, while the cross regulated sensitivity for prosocial neurotransmitters and neuropeptides like serotonin and oxytocin might have increased steadily, eventually forming a positive feedback loop.

Fifth, in dogs and humans, there are common genetic signatures of selection in physiological processes involved in domestication. In particular, mutations and changes in methylation patterns in the oxytocin receptor gene, $O X T R$, have been found in samples of dogs compared to wolves, providing evidence that this gene might have played an active role in dog domestication (Oliva et al., 2016; Shilton et al., 2020; vonHoldt et al., 2020). Likewise, signatures of positive selection in cis-regulatory sequences of $O X T R$ have been found in humans (Schaschl et al., 2015). And in both humans and dogs the genetic variation of OXTR is linked with differences in social behaviour (Eales, 1989; Pfenning et al., 2014; Shilton et al., 2020), whereas this correlation is not found in wolves (Nagasawa et al., 2015).

Sixth, more specifically, human-dog contacts might promote self-domestication features in humans. Accordingly, several clinical conditions entailing behavioural, cognitive, and language problems exhibit as well altered features of human self-domestication. For instance, people with schizophrenia show exacerbated signs of self-domestication at the physical, behavioural, cognitive, and linguistic levels (Benítez-Burraco et al., 2017). Adult patients suffering on chronical schizophrenia benefits from dog facilitated therapy, showing more prosocial interactions to other patients (Nathans-Barel et al., 2005; Villalta-Gill et al., 2009). Notably too, autism spectrum disorders (ASD) show attenuated features of domestication (Benítez-Burraco et al., 2016). Noticeably, people with ASD 
are often more interested in social and communicative contacts with dogs than with humans (Siewertsen, 2015; Valiyamattam et al., 2019). Studies have shown positive effects of dog facilitated therapy for people with ASD, including increased social interaction, enhanced social learning abilities and communication, and reduced stress (Sams et al., 2006; Prothmann et al., 2009; Beetz et al., 2012; O’Haire, 2013; Julius et al., 2014; Siewertsen, 2015; Carlisle, 2015; Wijker et al., 2019), all of which are expected outcomes of the human self-domestication process, as reviewed in the previous section. These effects can be linked in turn to specific epigenetic and physiological aspects of stress response and of prosocial behaviour involved in human-dog attachment and eventually, in human-dog co-domestication. Hence, ASD is characterized by abnormally decreased levels of oxytocin (Modahl et al., 1998), reduced density of the OTXR in the brain (Haas and Smith, 2015), and an hypermethylation of the promotor region of OXTR (Haas and Smith, 2015; Andari et al., 2020), which correlate with clinical symptoms and with reduced connectivity between cortico-cortical areas involved in ToM (Andari et al., 2020). Nasal oxytocin release can increase the attention to social stimuli and their understanding by subjects with ASD (Domes et al., 2013, 2014; Gordon et al., 2016). It seems plausible that interactions with dogs result in increased oxytocin levels and ultimately, in the improvement of patients' social, emotional und cognitive functioning (although there is still no direct evidence for this, an analogy can be drawn with oxytocin increases due to dog-human interactions in neurotypical groups, as well as with the social benefits of nasal oxytocin release in ASD patients; see also Odendaal 2000; Odendaal and Meintjes, 2003; Miller et al., 2009; Nagasawa et al., 2009; Handlin et al., 2011; Beetz et al., 2012; Wijker et al., 2019; Powell et al., 2020). Likewise, reduced cortisol awakening responses compared to their peers have been observed in children with ASD with contact to an assistance dog (Viau et al., 2010). 
Seventh, the close relationship between man and dog, closer in fact than with any other species, results in a high number of diseases suffered by both, especially mental diseases, which reflect a similar lifestyle with intimate contacts between species (Zhang et al., 2020). Therefore, dog has become an attractive model for medical, especially psychopharmacological research. Interestingly, some of these diseases can be related to domestication, particularly conditions affecting cognition and behaviour. On the human side, as noted, high prevalent cognitive diseases impacting on our cognitive architecture, like ASD or schizophrenia, have been linked to an abnormal presentation of selfdomestication features (Benítez-Burraco et al., 2016; 2017). On the dog side, many diseases are mental diseases too (Shearin and Ostrander, 2010b; Ostrander et al., 2017). In some cases, we can find common etiological factors accounting for human and canine diseases. One interesting instance is canine compulsive disorder (CCD), which parallels human obsessive compulsive disorder (OCD). Both CCD and OCD have been associated to the $C D H 2$ gene (Dodman et al., 2010; Moya et al., 2013; Tang et al., 2014). Variants of $\mathrm{CDH} 2$ can also contribute to Tourette syndrome (TS), a tic disorder which is sometimes accompanied by production of derogatory language (Moya et al., 2013). CCD, OCD and TS are hereditary conditions that seem to be triggered by environmental stressors resulting in abnormal patterns of inhibition/disinhibition (mostly imbalanced serotonergic and dopaminergic pathways) in the cortico-striatal-thalamic-cortical loop (Vermeire et al., 2012).TS has been highlighted as a proxy or window to previous stages in human selfdomestication entailing higher levels of reactive aggression (see Progovac and BenítezBurraco, 2019 for details). 
Finally, there is an intriguing convergence as well on the genetic basis of aspects of dog domestication, human self-domestication, and human cognitive disease impacting on social and communicative abilities. To begin with, genes positively selected in humans compared to extinct hominins are enriched in candidates for mammal domestication, particularly, dog domestication (Theofanopoulou et al., 2017). Likewise, genes that are found dysregulated in the blood of people with ASD are enriched in candidates for mammal domestication (Benítez-Burraco, 2020). More specifically, a genomic region found to be under positive selection in domestic dog breeds causes Williams syndrome (WS) in humans when deleted (vonHoldt et al., 2017). WS is a clinical condition resulting from the loss of around 30 genes from one of the copies of chromosome 7 (Pober, 2003). Subjects with this condition exhibit a distinctive phenotype, including altered growth patterns, craniofacial anomalies resulting in an 'elfin' face, heart disease, mental retardation and impaired visuospatial cognition, spared sociability and musical abilities, and notable language abilities (Mervis and Becerra 2007; Pober, 2010; Morris, 2010). Interestingly, WS also involves exacerbated features of human self-domestication (Niego and Benitez-Burraco, 2019), while genes dysregulated in the blood on people with WS are also enriched in genes positively selected in humans compared to Neanderthals (Benítez-Burraco, 2019). Hypersociability, a central feature of both WS and dogs compared to wolves can be linked to structural variants of GTF2I and GTF2IRD1, two of the genes within the WS region (vonHoldt et al., 2017), but also to the altered expression of several others, including $B A Z 1 B$ (vonHoldt et al., 2018). This gene is a robust candidate for domestication in mammals (Wilkins et al., 2014). It also contributes to regulate the balance between neural precursor self-renewal and differentiation (Lalli et al., 2016). Interestingly too, Zanella and colleagues (2019) have recently found a modern-specific enrichment for regulatory changes both in $B A Z 1 B$ and its downstream targets. Finally, 
consider as well that WS is associated with abnormally decreased DNA methylation of OXTR, perhaps because of altered functioning of methyltransferase genes located within the WS locus (Haas and Smith, 2015). Thus, an interface between genes of the WS region and the (epigenetic modulation of the) HPA axis can be hypothesised, with this interface influencing the serotonin and oxytocin system, and ultimately, social behaviour. Overall, these molecular findings suggest that in dogs, selection towards domestication targeted a limited set of behavioural genes (several of them in the WS region) with larger phenotypic effects that facilitated the coexistence with humans. But the same might have occurred in humans, with alterations of the WS region playing a key role in the evolution of the modern human face and prosociality.

\section{Language evolution in a potential scenario of human-dog coevolution}

In the last part of the paper, we will hypothesize about the consequences of a putative human-dog co-domestication scenario on the evolution of communication abilities. On the dog side, the effects of their coexistence and interaction with humans on their communication abilities are expected to be notable. Domestication seemingly involved the emergence (or the reinforcement) in first wolf-dogs of human-like social skills important for communicating, particularly, joint attention (Nagasawa et al., 2015) and following human referential gestures (Kaminski and Nitzschner, 2013; Range and Viranyi, 2013), eventually leading to over-imitation (Huber et al., 2020). Over-imitation refers to the eagerness to copy causally irrelevant actions. It is prevalent in humans, but is totally absent in great apes. Present day dogs exhibit enhanced communication abilities with humans. Contrary to wolves, dogs look back at humans (Miklosi et al., 2003). Dogs have not only learned to interpret human gestures, including cues for help, but they are 
actively looking for them pretty much human toddlers do (MacLean et al., 2017). Even free-ranging dogs can understand human cues, including complex human pointing gestures (Bhattacharjee et al., 2020). Dogs are capable of recognizing finest human emotions. i.e. non-verbal behaviour (Albuquerque et al., 2015). At the same time, dogs play an active role in this interspecific non-verbal communication. For instance, human attention increases the number of facial movements and expressions by dogs, this being suggestive of a communicative intention (Kaminski et al., 2017). Facial movements addressed to humans differ from facial expression directed to their conspecifics (Cátia et al., 2017). Evolutionarily, we can trace these changes to changes in facial muscle anatomy (Diogo et al., 2018; Sexton, 2019). Accordingly, in the very short time of the evolution from wolf to dog, a completely new muscle was added: the levator anguli oculi medialis, which is responsible for raising the inner eyebrow intensely and which supports facial movements that are interpreted by human caregivers as a social bonding cue, e.g. as a friendly begging (Kaminski et al, 2019; Sexton 2019). As a matter of fact, also the distinctive human face (short and retracted beneath a large globular braincase) has been hypothesized to have evolved under the effect of social influences (LaCruz et al., 2019). In truth, the childish features of the human face can be linked to domestication, as domestication commonly results in neotenic features (see Wilkins et al., 2014 for discussion). Sánchez-Villagra and van Schaik (2019) have suggested that our distinctive face might have acted as a signal of friendliness and social tolerance, contributing to increased in-group and particularly, inter-group contacts.

But not only non-verbal communication abilities have improved in dogs as a result of contacting with humans. Dogs seem to have shaped a special ability for interpreting human language (Fugazza and Miklósi, 2020). Border collies are able to comprehend 
object names as verbal referents of more than 1,000 objects (Pilley and Reid, 2011). Dogs are able to identify new objects only by object names (Fugazza and Miklósi, 2020). They are able to fast map, inferring the spoken names of novel items by exclusion learning and correctly retrieved those items right away (Kaminski et al., 2004). fMRI experiments suggest that words and non-words are processed in dogs by different neural networks, with the former involving basic processes like novelty detection, as well as auditory and hedonic representations (Prichard et al., 2018). Interestingly, likewise humans, dogs also process words with a hemispheric bias, with lexical and intentional aspects being processed separately (Andics et al., 2016). These human-language orientated skills are remarkable if one considers that dog barking lacks most of the features defining human language, particularly compositionality and duality of pattern. During dog domestication, barking became a normal vocal communication for dogs e.g. as a hunting partner (Perri, 2019). Wolves only bark very briefly and only in some rare cases (Mech and Boitani, 2010; Faragó et al., 2013). Dog barking can thus be interpreted as an adaptation to human speech-based communication (Pongraz et al., 2010). If one recalls the positive selection in dogs of genes within the WS region, it is somehow intriguing that subjects with WS show enhanced musicality and expressivity, commonly expressed through a heightened emotional responsiveness to music (Thakur et al., 2018).

On the human side, as discussed in the previous section, full self-domestication is expected to have brought not merely reduced reactive aggression, an hypersocial behaviour and increased cooperation skills, but also improved social learning, working memory, emotional inhibition, executive functions as well as improved ToM, ultimately rooting on changes in brain function and anatomy due to increased interspecific prosocial contacts (this is sometimes called the model of "Active Social Domestication"; see Pörtl 
and Jung, 2017, 2018 for details). All these are important changes for achieving enhanced communication abilities. Specifically, as noted in the introduction, these changes are expected to account for those aspects of languages resulting from a cultural process (Thomas and Kirby, 2018; Progovac and Benítez-Burraco, 2019; Benítez-Burraco and Progovac, submitted). Hence, reduced reactive aggression resulting from our increased self-domestication has been linked to increased structural complexity of languages, with more sophisticated verbal behaviour and enhanced self-domestication features being involved in a positive feed-back loop (Progovac and Benítez-Burraco, 2019). Also modern uses of languages (i.e. pragmatics) are expected to have been modelled by our increased self-domestication, particularly, because reduced reactive aggression and enhanced prosocial behaviour seemingly facilitated the potentiation of pragmatic principles governing conversation, including, turn-taking and conversational implicature (see Benítez-Burraco and Progovac, submitted and references herein for further discussion). Pretty obviously, if man-dog coexistence and interaction contributed to exacerbate our self-domestication features, as discussed in the previous section, they should have impacted on our language abilities too, including language structure and use, as suggested above.

Overall, selection for tameness and cooperation, and therefore, less reactive aggression and increased self-control, can be expected to have resulted in changes in verbal and nonverbal communication in both dogs and humans. Ultimately, it is tentative to hypothesize that AMHs improved, even subtly, their ability to communicate with non-kin groups by first interacting with non-kin species (wolf/dog). After all, dog domestication predates the emergence of extensive human social networks involving non-related individuals, which become generalized non earlier than the Magdalenian period, around 12 kya 
(Vanhaeren and d'Errico, 2006; Schwendler, 2012). This ability for interacting with nonkin underlies the last stages in language evolution, to be precise, the emergence of the socalled exoteric languages, that are better suited for conveying decontextualized meanings to strangers (see Benítez-Burraco and Progovac in press for details).

\section{Conclusions}

In this paper we have explored the consequences of human-dog interaction for the evolution of their cognitive and behavioural distinctive features, with a focus on communication and ultimately, on language abilities by humans. We have first explored the parallels between dog domestication and human self-domestication. We have then argued in favour of a scenario of dog-human coevolution resulting from this interaction, impacting significantly on behavioural and cognitive abilities via the physiological mechanisms responsible for stress and aggression management. We have further argued in favour of dog domestication and human self-domestication being engaged in a positive feedback loop. This feedback effect seemingly contributed to increase their prosocial behaviour and socio-cognitive abilities, and ultimately, their communication skills, which in the case of humans facilitated the emergence of modern languages, paving the way for widespread social networks and ultimately, larger communities and civilizations.

\section{References}


Albuquerque, N., Guo, K., Wilkinson, A., Savalli, C., Otta, E., \& Mills, D. (2016).

Dogs recognize dog and human emotions. Biol. Lett., 12, 20150883.

https://doi.org/10.1098/rsbl.2015.0883.

Amici, F., Sánchez-Amaro, A., Sebastián-Enesco, C., Cacchione, T., Allritz, M., SalazarBonet, J., \& Rossano, F. (2019). The word order of languages predicts native speakers' working memory. Sci Rep. 9(1), 1124. doi: 10.1038/s41598-018-37654-9.

Andari, E., Nishitani, S., Kaundinya, G., Caceres, A. G., Michael J., Morrier, O., Smith, A. K., Cubells J. F., \& Young, L. J. (2020). Epigenetic modification of the oxytocin receptor gene: implications for autism symptom severity and brain functional connectivity. Neuropsychopharmacol., https://doi.org/10.1038/s41386-020-0610-6.

Andics, A., Gábor, A., Gácsi, M., Faragó, T., Szabó, D., \& Miklósi, Á. (2016). Neural mechanisms for lexical processing in dogs. Science, 353(6303), 1030-1032. https://DOI: 10.1126/science.aaf3777.

Arai, J. A., Li, S., Hartley, D. M., \& Feig, L. A. (2009). Transgenerational rescue of a genetic defect in long-term Potentiation and memory formation by juvenile enrichment. J. Neurosci., 29(5), 1496-1502. https://doi.org/10.1523/JNEUROSCI.5057-08.2009

Avital, E., \& Jablonka, E. (2000). Animal traditions: behavioural inheritance in evolution. Cambridge University Press, Cambridge, (431 ISBN 0-521-66273-7). 
Axelsson, E., Ratnakumar, A., Arendt, M-J., Maqbool, K., Webster M.T., \& LindbladToh, K. (2013). The genomic signature of dog domestication reveals adaptation to a starch-rich diet. Nature, 495, 360 -364. https://doi.org/10.1038/nature11837

Barker, S. B., Knisely, J. S., McCain, N.L., \& Best, A.M. (2005). Measuring stress and immune response in healthcare professionals following interaction with a therapy dog: a pilot study. Psychol. Rep., 96, 713-29. https://doi:10.2466/pr0.96.3.713-729

Bartal, I.B., Decety, J., \& Mason P. (2011). Empathy and pro-social behavior in rats. Science, 334, 1427-1430.

Beetz, A., Kotrschal, K., Turner, D., Hediger, K., Uvnäs-Moberg, K., \& Julius, H. (2011). The effect of a real dog, toy dog and friendly person on insecurely attached children during a stressful task: An exploratory study. Anthrozoös, 24(4), 349-368.

Beetz, A., Uvnäs-Moberg, K., Julius, H., \& Kotrschal, K. (2012). Psychosocial and Psychophysiological effects of human-animal interactions: The possible role of Oxytocin. Front. Psychol., 3, 234. https://doi.org/10.3389/fpsyg.2012.00234.

Benítez-Burraco, A. (2019). Genes dysregulated in the blood of people with Williams Syndrome are enriched in protein-coding genes positively selected in humans. Eur J Med Genet 30, 103828. doi: 10.1016/j.ejmg.2019.103828

Benítez-Burraco, A. (2019). Prehistoric languages and human self-domestication. Lang Dyn Change doi.org/10.1163/22105832-01001400 
Benítez-Burraco, A. (2020). Genes positively selected in domesticated mammals are significantly dysregulated in the blood of people with Autism Spectrum Disorders. Mol Syndromol 10(6), 306-312 doi: 10.1159/000505116

Benítez-Burraco, A., \& Progovac, L. (in press) A four-stage model for language evolution under the effects of human self-domestication. Lang Comm

Benítez-Burraco, A., \& Progovac, L. (submitted) Human self-domestication, pragmatics, and language evolution. Front. Psychol.

Benítez-Burraco, A., Chekalin, E., Bruskin, S., \& Morozova, I. (2019). Recent changes in candidate genes for domestication in humans in Europe: focusing on language. BioRxiv doi: https://doi.org/10.1101/684621

Benítez-Burraco, A., Di Pietro, L., Barba, M., \& Lattanzi, W. (2017). Schizophrenia and human self-domestication: an evolutionary linguistics approach. Brain Behav Evol 89(3), 162-184 doi: 10.1159/000468506.

Benítez-Burraco, A., Lattanzi, W., \& Murphy, E. (2016). Language impairments in ASD resulting from a failed domestication of the human brain. Front Neurosci. 10, 373. doi: 10.3389/fnins.2016.00373

Benítez-Burraco, A., Theofanopoulou, C., \& Boeckx, C. (2018). Globularization and domestication. Topoi 37, 265-278 doi: 10.1007/s11245-016-9399-7 
Bhattacharjee, D., Mandal, S., Shit, P., Varghese, M. G., Vishnoi, A., \& Bhadra, A. (2020). Free-Ranging dogs are capable of utilizing complex human pointing cues. Front. Psychol., 10, 2818. https://doi:10.3389/fpsyg.2019.02818.

Böhnke, R., Bertsch, K., Kruk, M.R., \& Naumann, E. (2010). The relationship between basal and acute HPA axis activity and aggressive behavior in adults. J. Neural. Transm., 117(5), 629-637. https://doi:10.1007/s00702-010-0391-x.

Botigué, L.R., Song, S., Scheu, A., Gopalan, S., Pendleton, A., Oetjens, M., Taravella, A., Seregély, T., Zeeb-Lanz, A., Arbogast, R., Bobo, D., Daly, K., Unterländer, M., Burger, J., Kidd J., \& Veeramah, K. (2017). Ancient European dog genomes reveal continuity since the Early Neolithic. Nat. Commun., 8, 16082 https://doi:10.1038/ncomms 16082.

Brusini, I., Carneiro, M., Wang, C., Rubin, C. J., Ring H., Afonso, S., Blanco-Aguiar, J. A., Ferrand, N., Rafati, N., Villafuerte, R., Smedby, Ö., Damberg, P., Hallböök, F., Fredrikson M., \& Andersson, L. (2018). Changes in brain architecture are consistent with altered fear processing in domestic rabbits. Proc. Nat. Acad. Sci. U S A, 115(28), 7380-7385. https://doi:10.1073/pnas.1801024115.

Caeiro, C., Guo, K., \& Mills, D. (2017). Dogs and humans respond to emotionally competent stimuli by producing different facial actions. Sci. Rep., 7, 15525. https://doi.org/10.1038/s41598-017-15091-4. 
Cagan, A., Blass, T. (2016). Identification of genomic variants putatively targeted by selection during dog domestication. BMC Evol. Biol., 16, 10. https://doi.org/10.1186/s12862-015-0579-7.

Carlisle, G. K. (2015). The social skills and attachment to dogs of children with autism spectrum disorder. J. Autism Dev. Disord., 45(5), 137-45. https://doi: 10.1007/s10803014-2267-7.

Catala, A., Mang, B., Wallis, L., \& Huber, L. (2017). Dogs demonstrate perspective taking based on geometrical gaze following in a Guesser-Knower task. Animal Cog., 20, 581-589. https://doi.org/10.1007/s10071-017-1082-x.

Cieri, R. L., Churchill, S. E., Franciscus, R. G., Tan, J., \& Hare, B. (2014). Craniofacial feminization, social tolerance, and the origins of behavioral modernity. Curr Anthropol. $55,419-43$.

Clarke, E., Heyes, C. (2017). The swashbuckling anthropologist: Henrich on The Secret of Our Success. Biol Philos. 32(2), 289-305.

Coulson, D., \& Campbell, A. (2001). African rock art: Paintings and engravings on stone. New York: Harry N Abrams.

Covington, N. V., \& Duff, M. C. (2016). Expanding the language network: Direct contributions from the hippocampus. Trends Cogn. Sci., 20(12), 869-870. https://doi: 10.1016/j.tics.2016.10.006. 
Darimont, C. T., Stronen, A. V., Navid, E. R., Quinn, M. S., Paquet, P. C., \& Bryan, H. M. (2014). Population genetic structure of gray wolves (Canis lupus) in a marine archipelago suggests island-mainland differentiation consistent with dietary niche. $B M C$ Ecol., 14, 11. https://doi.org/10.1186/1472-6785-14-11.

Darwin, C. R. (1860). On the origin of species by means of natural selection, or the preservation of favoured races in the struggle for life. London: John Murray 2nd edition.

de Waal, F., Dindo, M., Freeman, C. A., \& Hall, M. J. (2005). The monkey in the mirror: Hardly a stranger. Proc. Nat. Acad. Sci. USA 102(32), 11140-11147; https://doi.org/10.1073/pnas.0503935102.

Diogo, R., Ziermann, J. M., Molnar, J., Siomava, N., \& Abdala, V. (2018). Muscles of Chordates: Development, Homologies, and Evolution. CRC Press, Boca Raton, ISBN13: $978-1138571235$.

Dodman, N. H. Karlsson, E. K., Moon-Fanelli, A., Galdzicka, M., Perloski, M., Shuster, L., Lindblad-Toh, K. \& Ginns, E. I. (2010). A canine chromosome 7 locus confers compulsive disorder susceptibility. Mol. Psychiatry, 15, 8-10.

Domínguez-Rodrigo, M., \& Pickering, T. R. (2017). The meat of the matter: an evolutionary perspective on human carnivory. Azania, 52, 4-32. https://doi: 10.1080/0067270x.2016.1252066. 
Eales, L. A. (1989). The influences of visual and vocal interaction on song learning in zebra finches. Anim. Behav., 37, 507-508. https://doi:10.1016/0003-3472(89)90097-3.

Faragó, T., Townsend, S., \& Range, F. (2014). The information content of wolf (and dog) social communication. In: Witzany G. (eds) Biocommunication of animals. Springer, Dordrecht

Ferrari, P. F. (2016). Neurobiology of empathy, a lesson from primates. Dog Behav., 2, 3 https://doi.org/10.4454/db.v2i3.44.

Filatova, O. A., Samarra, F., Deecke, V. B., Ford, J., Miller, P., \& Yurk, H. (2015). Cultural evolution of killer whale calls: Background, mechanisms and consequence. Behavior, 152(15), 2001-2038. https://DOI:10.1163/1568539X-00003317.

Foote, A. D., Vijay, N., Ávila-Arcos, M., \& Wolf, B. W. (2016). Genome-culture coevolution promotes rapid divergence of killer whale ecotypes. Nat. Comm., 7, 11693. https://doi: 10.1038/ncomms11693.

Frederick, E. (2019). Humans haven't just changed what dogs look like-we've altered the very structure of their brains. Plants \& Animals, Sep. 2, https://doi:10.1126/science.aaz3324. 
Friedmann, E., Katcher, A. H., Thomas, S. A., Lynch J. J., \& Messent, P. R. (1983).

Social interaction and blood pressure: Influence of animal companions. J. Nerv. Ment. Dis., 171, 461-464. https://doi.10.1097/00005053-198308000-00002.

Fugazza, C., \& Miklósi, Á. (2020). Depths and limits of spontaneous categorization in a family dog. Sci. Rep., 10, 3082. https://doi.org/10.1038/s41598-020-59965-6.

Fukase, H., Kondo, O., \& Ishida, H. (2015). Size and placement of developing anterior teeth in immature Neanderthal mandibles from Dederiyeh Cave, Syria: implications for emergence of the modern human chin. Am J Phys Anthropol. 156, 482-488. doi: 10.1002/ajpa.22665.

Germonpré, M., Láznicková-Galetová, M., \& Sablin, M. B. (2012). Palaeolithic dog skulls at the Gravettian Predmostí site, the Czech Republic. J. Archaeol Sci., 39(1), 184-202. https://doi.org/10.1016/j.jas.2011.09.022.

Germonpré, M., Láznicková-Galetová, M., Losey, R. J., Räikkönen, J., \& Sablin, M. V. (2015). Large canids at the Gravettian Predmostí site, the Czech Republic: The Mandible. Quatern Int., 359-360, 261-279. https://doi.org/10.1016/j.quaint.2014.07.012

Germonpré, M., Sablin, M. V., Stevens, R. E., Hedges, R. E. M., Hofreiter, M., Stiller, M., \& Després, V. R. (2009). Fossil dogs and wolves from Palaeolithic sites in Belgium, the Ukraine and Russia: osteometry, ancient DNA and stable isotopes J. Archaeol Sci., 36(2), 473-490. https://doi.org/10.1016/j.jas.2008.09.033 
Gou, X., Wang, Z., Li, N., \& Li, Y. (2014). Whole-genome sequencing of six dog breeds from continuous altitudes reveals adaptation to high-altitude hypoxia. Genome Res., 24(8), 1308-1315 https://doi:10.1101/gr.171876.113.

Grossberg, J. M., \& Alf, E. F. (1985). Interaction with pet dogs: Effects on human cardiovascular response. J. Delta Soc., 2, 20-27.

Guagnin, M., Perri, A., \& Petraglia, M. (2018). Pre-Neolithic evidence for dog-assisted hunting strategies in Arabia. J. Anthrop. Archaeol, 49, 225-236.

https://doi.org/10.1016/j.jaa.2017.10.003.

Haas, B. W., \& Smith, A. K. (2015). Oxytocin, vasopressin, and Williams syndrome: epigenetic effects on abnormal social behavior. Front. Genet., 6, 28. https://doi: 10.3389/fgene.2015.00028.

Handlin, L., Hydbring-Sandberg, E., Nilsson, A., Ejdebäck, M., Jansson, A., \& UvnäsMoberg, K. (2011). Short-term interaction between dogs and their owners - effects on oxytocin, cortisol, insulin and heart rate - an exploratory study. Anthrozoos, 24(3), 301315. 2752/175303711X13045914865385.

Hansen, K. M., Messenger, C. J., Baun, M., \& Megel, M. E. (1999). Companion animals alleviating distress in children. Anthrozoos, 12(3), 142-148. 2752/089279399787000264. 
Hare, B. (2017). Survival of the friendliest: Homo sapiens evolved via selection for prosociality. Ann. Rev. Psychol, 68, 155-186. https://doi:10.1146/annurev-psych010416-044201.

Hare, B., Wobber, V., \& Wrangham, R. (2012). The self-domestication hypothesis:

Evolution of bonobo psychology is due to selection against aggression. Anim Behav., 83, 573-585. https://doi:10.1016/j.anbehav.2011.12.007

Harveson, P., Lopez, R., Collier, B., \& Silvy, N. (2007). Impacts of urbanization on Florida Key deer behavior and population dynamics. Biol. Conserv, 134(3), 321-331. 10.1016/j.biocon.2006.07.022

Havener, L., Gentes, L., Thaler, B., Megel, M. E., Baun, M. M., Driscoll, F. A., Beiraghi, S., \& Agrawal, S. (2001). The effects of a companion animal on distress in children undergoing dental procedures. Iss. Compr. Pediatr. Nurs., 24, 137-152. https://doi:10.1080/01460860118472.

Hawkes, K. (2003). Grandmothers and the evolution of human longevity. Am. J. Hum. Biol., 15(3), 380-400. https://doi:10.1002/ajhb.10156.

Hecht, E. E. (2019). Significant neuroanatomical variation among domestic dog breeds. J. Neurosci. 39(39), 7748-7758. https://doi.org/10.1523/JNEUROSCI.0303-19.2019. 
Hernádi, A., Kis, A., Turcsán, B., \& Topál, J. (2012). Man's underground best friend: domestic ferrets, unlike the wild forms, show evidence of dog-like social-cognitive skills. PLoS One 7, e43267.

Herrmann, E., Hare, B., Cissewski, J., \& Tomasello, M. A. (2011). Comparison of temperament in nonhuman apes and human infants. Dev Sci. 14, 1393-1405.

Holl, A. (2004). Saharan Rock Art, Archaeology of Tassilian Pastoralist Icongraphy AltaMira. Oxford: Press, Walnut Creek.

Huang, S., Slomianka, L., Farmer, A. J., Kharlamova, A. V., Gulevich, R. G., Herbeck, Y. E., Trut, L., Wolfer, D. P., \& Amrein, I. (2015). Selection for tameness, a key behavioral trait of domestication, increases adult hippocampal neurogenesis in foxes. Hippocampus, 25(8), 963-75. https://doi:10.1002/hipo.22420.

Huber, L., Salobir, K., Mundry, R., \& Cimarelli, G. (2020). Selective overimitation in dogs. Learn. Behav., Jan 23. https://doi:10.3758/s13420-019-00400-w.

Janssens, L., Giemsch, L., Schmitz, R., Street, M., Van Dongen, S., \& Crombé, P. (2018). A new look at an old dog: Bonn-Oberkassel reconsidered. J. Archaeol Sci. https://doi.org/10.1016/j.jas.2018.01.004.

Julius, H., Beetz, A., \& Kotrschal, K. (2014). Bindung zu Tieren: Psychologische und neurobiologische Grundlagen tiergestützter Interventionen. Hogrefe, Göttingen. 
Jung, C. (2011). Rassehund am Ende? Norderstedt: BoD.

Jung, C., \& Pörtl, D. (2015). Tierisch beste Freunde: Mensch und hund - von streicheln, stress und oxytocin. Stuttgart: Schattauer Verlag für Medizin und Naturwissenschaften.

Jung, C., \& Pörtl, D. (2018). Scavenging hypothesis: Lack of evidence for dog domestication on the waste dump. Dog Behav., 4(2), 41-56.

https://doi.org/10.4454/db.v4i2.73.

Jung, C., \& Pörtl, D. (2019). How old are (pet) dog breeds? Pet Behav. Sci., 7, 29-37. https://doi.org/10.21071/pbs.v0i7.11494.

Kaminski, J., \& Nitzschner, M. (2013). Do dogs get the point? A review of dog-human communication ability. Learn Motiv. 44(4), 294-302.

https://doi.org/10.1016/j.lmot.2013.05.001.

Kaminski, J., Call, J., \& Fischer, J. (2004). Word learning in a domestic dog: Evidence for "fast mapping". Science, 304(5677), 1682-1683.

https://DOI:10.1126/science.1097859.

Kaminski, J., Hynds, J., Morris, P., \& Waller, B. M. (2017). Human attention affects facial expressions in domestic dogs. Sci. Rep., 7, 12914. https://doi.org/10.1038/s41598017-12781-x. 
Kaminski, J., Waller, B. M., Diogo, R., Hartstone-Rose, A. \& Burrows, A. M. (2019). Evolution of facial muscle anatomy in dogs. Proc. Nat. Acad. Sci. U S A, 116(29), 14677-14681. https://doi.org/10.1073/pnas.1820653116.

Kelly, J. J., Mangos, G., Williamson, P. M., \& Whitworth, J. A. (1998). Cortisol and hypertension. Clin. Exp. Pharmacol. Physiol. Suppl., 25, 51-S56.

https://doi:10.1111/j.1440-1681.1998.tb02301.x.

Kepinska, O., de Rover, M., Caspers, J., \& Schiller, N. O. (2018). Connectivity of the hippocampus and Broca's area during acquisition of a novel grammar. Neuroim., 165 , 1-10. https://doi:10.1016/j.neuroimage.2017.09.058.

Kilner, J. M., \& Lemon, R. N. (2013). What we know currently about mirror Neurons. Curr. Biol., 23(23), 1057-1062. 10.1016/j.cub.2013.10.051

Kobayashi, Y., Wakano, J. Y., \& Ohtsuki, H. (2019). Evolution of cumulative culture for niche construction. J Theor Biol 472, 67-76. doi: 10.1016/j.jtbi.2019.04.013.

Kosfeld, M., Heinrichs, M., Zak, P. J., Fischbacher, U., \& Fehr, E. (2005). Oxytocin increases trust in humans. Nature, 435(7042), 673-676.

https://doi:10.1038/nature03701.

Kotrschal, K. (2018). How Wolves Turned into Dogs and How Dogs Are Valuable in Meeting Human Social Needs. People and Animals: The Intern. J. of Research and Practice, 1(1), 6. https://docs.lib.purdue.edu/paij/vol1/iss1/6. 
Lacruz, R. S., Stringer, C. B., Kimbel, W. H., et al. (2019). The evolutionary history of the human face. Nat. Ecol Evol, 3, 726-736.

Laland, K., Odling-Smee, J., \& Feldman, M. (2000). Niche construction, biological evolution, and cultural change. Behav. Brain Sci. 23(1), 131-146. doi:10.1017/S0140525X00002417

Lalli, M. A., Jang, J., Park, J. H., Wang, Y., Guzman, E., Zhou, H., Audouard, M., Bridges, D., Tovar, K. R., Papuc, S. M., Tutulan-Cunita, A. C., Huang, Y., Budisteanu, M., Arghir, A., \& Kosik, K. S. (2016). Haploinsufficiency of BAZ1B contributes to Williams syndrome through transcriptional dysregulation of neurodevelopmental pathways. Hum. Mol. Genet, 25, 1294-1306. https://doi: 10.1093/hmg/ddw010.

Lamm, C., Batson, C. D., \& Decety, J. (2007). The neural substrate of human empathy: effects of perspective-taking and cognitive appraisal. J. Cogn. Neurosci., 19(1), 42-58.

Leach, H. M. (2003). Human domestication reconsidered. Curr Anthropol. 44, 349-368.

Lewejohann, L., Pickel, T., Sachser, N., \& Kaiser, S. (2010). Wild genius - domestic fool? Spatial learning abilities of wild and domestic guinea pigs. Front Zool. 7, 9.

Li, J., Zhao Y., Li, R., Broster, L. S., Zhou, C., \& Yang, S. (2015). Association of oxytocin receptor gene (OXTR) rs53576 polymorphism with sociality: A MetaAnalysis. PLoS One, 10, 0131820. 
Losey, R. J., Bazaliiskii, V. I., Garvie-Lok, S., Germonpré, M., Leonard, J. A., Allen, A. L., Katzenberg, A. M., Sablin, M. V., (2011). Canids as persons: early Neolithic dog and wolf burials, Cis-Baikal, Siberia. J Anthropol Archaeol, 30, 174-189.

Losey, R. J., Garvie-Lok, S., Leonard, J. A., Katzenberg, A.M., Germonpré, M., Nomokonova, T., Sablin, M. V., Goriunova, O. I., Berdnikova, N. E., \& Savel'ev, N. A., (2013). Burying dogs in ancient Cis-Baikal, Siberia: temporal trends and relationships with human diet and subsistence practices. PLoS One, 8(5), 63740.

Lupyan, G., \& Dale, R. (2010). Language structure is partly determined by social structure. PLoS One 5, e8559.

MacLean, E. L., Herrmann, E., Suchindran, S., \& Hare, B. (2017). Individual differences in cooperative communicative skills are more similar between dogs and humans than chimpanzees. Animal Behav., 126, 41-51.

https://doi.org/10.1016/j.anbehav.2017.01.005.

MacLean, E. L., Snyder-Mackler, N., vonHoldt, B. M., \& Serpell, J. A. (2019). Highly heritable and functionally relevant breed differences in dog behaviour. Proc. Biol. Sci., 9(286), 20190716. https://doi:10.1098/rspb.2019.0716.

Márquez, S., Pagano, A. S., Delson, E., Lawson, W., \& Laitman, J. T. (2014). The nasal complex of Neanderthals: an entry portal to their place in human ancestry. Anat. Rec. (Hoboken). 297, 2121-37. 
Marshall-Pescini, S., Cafazzo, S., Virányi, Z., \& Range, F. (2017) Integrating social ecology in explanations of wolf-dog behavioral differences. Curr. Opin Behav. Sci., 16, 80-86. https://doi.org/10.1016/j.cobeha.2017.05.002.

Marshall-Pescini, S., Ceretta, M., \& Prato-Previde, E. (2014). Do domestic dogs understand human actions as goal-directed? PLoS One, 9(9), e106530. https://doi:10.1371/journal.pone.0106530.

Marshall-Pescini, S., Passalacqua, C., Miletto Petrazzini, M. E., Valsecchi, P., \& PratoPrevide, E. (2012). Do dogs (Canis lupus familiaris) make counterproductive choices because they are sensitive to human ostensive cues? PLoS One, 7(4), e35437. https://doi:10.1371/journal.pone.0035437.

Marshall-Pescini, S., Virányi, Z., \& Range, F. (2015). The effect of domestication on inhibitory control: Wolves and dogs compared. PLoS One, 10(2), e0118469. https://doi:10.1371/journal.pone.0118469

McBrearty, S., \& Brooks, A. (2000). The revolution that wasn't: A new interpretation of the origin of modern human behavior. J. Hum. Evol. 39, 453-563.

McEwen, B. S., \& Morrison, J. H. (2013). The brain on stress: vulnerability and plasticity of the prefrontal cortex over the life course. Neuron, 79(1), 16-29. https://doi: 10.1016/j.neuron.2013.06.028. 
Meaney, M.J., \& Szyf, M. (2005). Maternal care as a model for experience-dependent chromatin plasticity? Trends Neurosci., 28,456-463.

Mech, L. D. (1999). Alpha status, dominance, and division of labor in wolf packs. Can. J. Zool, 77, 1196-1203.

Mech, L. D. (2009). Possible use of foresight, understanding, and planning by wolves hunting Muskoxen. Arctic, 60(2), 145-149.

Mech, L. D., \& Boitani, L. (2010). Wolves: behavior, ecology, and conservation. University of Chicago Press. ISBN 978-0-226-51698-1.

Mellars, P. (2002). Archeology and the origins of modern humans: European and African perspectives. In Tim J. Crow (Ed.), The Speciation of Modern Homo Sapiens (pp. 31-47). Oxford: Oxford University Press.

Mervis, C. B., \& Becerra, A. M. (2007). Language and communicative development in Williams syndrome. Ment. Retard Dev. Disabil. Res., 13, 3-15.

Miklosi A., Kubinyi, E., Topál, J., Gácsi, M., Virányi, Z., \& Vilmos Csányi (2003). A simple reason for a big difference: Wolves do not look back at humans, but dogs do. Curr. Biology. 13(9), 763-766. https://doi.org/10.1016/S0960-9822(03)00263-X.

Miller, S. C., Kennedy, C. C., DeVoe, D. C., Hickey, M., Nelson, T. \& Kogan, L. (2009). An examination of changes in oxytocin levels in men and women before and 
after interaction with a bonded dog, Anthrozoös, 22, 31-42.

https://DOI:10.2752/175303708X390455.

Modahl, C., Green, L., Fein, D., Morris, M., Waterhouse, L., Feinstein, C., \& Levin, H. (1998). Plasma oxytocin levels in autistic children. Biol. Psychiatry, 43, 270-277.

Montagrin, A., Saiote, C., \& Schiller, D. (2018). The social hippocampus. Hippocampus 28(9), 672-679. doi: 10.1002/hipo.22797.

Montoya, E. R., Terburg, D., Bos, P. A. \& van Honk, J. (2012). Testosterone, cortisol, and serotonin as key regulators of social aggression: A review and theoretical perspective. Motiv. Emot., 36(1), 65-73. https://doi:10.1007/s11031-011-9264-3.

Morey, D. F. (1994). The early evolution of the domestic dog. Am Sci, 82(4), 336-347.

Morey, D. F., \& Wiant, M. D. (1992). Early Holocene domestic dog burials from the North American Midwest. Curr. Anthropol., 33, 224-229.

Morris, C. A. (2010). Introduction: Williams Syndrome. Am J Med Genet C Semin Med Genet. 154C(2), 203-8. doi: 10.1002/ajmg.c.30266.

Moya, P. R., Dodman, N. H., Timpano, K. R., Rubenstein, L. M., Rana, Z., Fried, R. L., Reichardt, L. F., Heiman, G. A., Tischfield, J. A., King, R. A., Galdzicka, M., Ginns, E. I., \& Wendland, J. R. (2013). Rare missense neuronal cadherin gene (CDH2) variants in 
specific obsessive-compulsive disorder and Tourette disorder phenotypes. Eur. J. Hum. Genet, 21(8), 850-854.

Nagasawa, M., Kazataka, M., \& Kikusui, T. (2009). Attachment between humans and dogs. Jap. Psychol. Res., 51(3), 111-233.

Nagasawa, M., Kikusui, T., Onaka, T., \& Ohta, M. (2009). Dog's gaze at its owner increases owner's urinary oxytocin during social interaction. Horm. Behav., 55, 434441. https://10.1016/j.yhbeh.2008.12.002.

Nagasawa, M., Mitsui, S., En, S., Ohtani, N., Ohta, M., Sakuma, Y., Onaka, T., Mogi, K., \& Kikusui, T. (2015). Oxytocin-gaze positive loop and the coevolution of humandog bonds. Science 348(6232), 333-336. https://DOI:10.1126/science.1261022.

Nagasawa, M., Murai, K., Mogi, K., \& Kikusui, T. (2011). Dogs can discriminate human smiling faces from blank expressions. Anim. Cogn., 14, 525 -533. https://doi:10.1007/s10071-011-0386-5.

Nagengast, S. L., Baun, M., Megel, M. M., \& Leibowitz, J. M. (1997). The effects of the presence of a companion animal on physiological arousal and behavioral distress in children during a physical examination. J. Pediatr. Nurs., 12, 323-330. https://10.1016/S0882-5963(97)80058-9. 
Nathans-Barel, I., Feldman, P., Berger, B., Modai, I., \& Silver, H. (2005). Animalassisted therapy ameliorates anhedonia in schizophrenia patients. Psychother. Psychosom., 74, 31-35. https://10.1159/000082024.

Neubauer, S., Hublin, J. J., \& Gunz, P. (2018). The evolution of modern human brain shape. Sci Adv. 4, eaao5961.

Niego, A., \& Benítez-Burraco, A. (2019). Williams syndrome, human self-domestication, and language evolution. Front Psychol. 10, 521.

Oberman, L. M., Pineda, J. A., \& Ramachandran, V. S. (2007). The human mirror neuron system: a link between action observation and social skills. Soc. Cogn. Affect Neurosci., 2(1), 62-66.

Odendaal, J. S. (2000). Animal-assisted therapy - magic or medicine? J. Psychosom. Res., 49, 275-280. https://10.1016/S0022-3999(00)00183-5.

Odendaal, J. S., \& Meintjes, R. A. (2003). Neurophysiological correlates of affiliative behavior between humans and dogs. Vet. J., 165, 296-301. https://10.1016/S10900233(02)00237-X.

O'Haire, M. E., Rodriguez, K. E. (2018). Preliminary efficacy of service dogs as a complementary treatment for posttraumatic stress disorder in military members and veterans. J. Consult Clin. Psychol., 86(2), 179-188. https://doi: 10.1037/ccp0000267. 
Okanoya, K. (2017). Sexual communication and domestication may give rise to the signal complexity necessary for the emergence of language: An indication from songbird studies. Psychon. Bull. Rev. 24, 106-110.

Oliva, J. L., Wong, Y. T., Rault, J.-L., Appleton, B., \& Lill, A. (2016). The oxytocin receptor gene, an integral piece of the evolution of Canis familaris from Canis lupus. Pet Behav. Sci., 1(2), 1-15. https://doi.org/10.21071/pbs.v0i2.4000.

Oliva, J.L., et al. (2019). Working smarter not harder: Oxytocin increases domestic dogs' (Canis familiaris) accuracy, but not attempts, on an object choice task. Front. Psychol., 10, 21-41. https://doi:10.3389/fpsyg.2019.02141.

Ollivier, M., Tresset, A., Bastian, F., Lagoutte L., Axelsson, E., Arendt, M. L., Balasescu, A., Marshour, M., Sablin, M. V., Salanova, L., Vigne, J. D., Hitte, C., \& Hänni, C. (2016). Amy2B copy number variation reveals starch diet adaptations in ancient European dogs. R. Soc. Open Sci., 3(11), 160449. https://doi:10.1098/rsos.160449.

Ostrander, E. A., Wayne, R. K., Freedman, A. H., \& Davis, B. W. (2017). Demographic history, selection and functional diversity of the canine genome. Nat. Rev. Genet, 18 (12), 705-720 P DOI:10.1038/nrg.2017.67.

Ovodov, N. D., Crockford, S. J., Kuzmin, Y. V., Higham, T. F. G., \& Hodgins, G. W. L. (2011). A 33,000-year-old incipient dog from the Altai Mountains of Siberia: 
Evidence of the earliest domestication disrupted by the last glacial maximum. PLoS One, 6(7), 22821. https://doi:10.1371/journal.pone.002282.

Page, A. E., Chaudhary, N., Viguier, S., Dyble, M., Thompson, J., Smith, D., Salali, G. D., Mace, R., \& Migliano, A. B. (2017). Hunter-Gatherer social networks and reproductive success. Sci. Rep., 7(1), 1153. https://doi:10.1038/s41598-017-01310-5.

Parker, H. G., Dreger, D. L., Rimbault, M., Davis, B. W., Mullen, A. B., Carpintero Ramirez. G., \& Ostrander. E. A. (2017). Genomic analyses reveal the influence of geographic origin, migration, and hybridization on modern dog breed development. Cell Rep., 19, 697-708.

Perri, A. (2016). Hunting dogs as environmental adaptations in Jomon Japan. Antiquity, 90(353), 1166-1180. https://doi:10.15184/aqy.2016.115.

Pfenning, A. R., Hara, E., Whitney, O., \& Jarvis, E. D. (2014). Convergent transcriptional specializations in the brains of humans and songlearning birds. Science, 346(6215), 1256846. https://doi:10.1126/science.1256846.

Piai, V., Anderson, K. L., Lin, J. J., Dewar, C., Parvizi, J., Dronkers, N. F., \& Knight, R. T. (2016). Direct brain recordings reveal hippocampal rhythm underpinnings of language processing. Proc Natl Acad Sci U S A., 113(40), 11366-11371. https://doi.org/10.1073/pnas.1603312113. 
Pilley, J. W., \& Reid, A. K. (2011). Border collie comprehends object names as verbal referents. Behav. Process, 86, 184-195. https:/doi: 10.1016/j.beproc.2010.11.007.

Pisor, A. C., \& Surbeck, M. (2019). The evolution of intergroup tolerance in nonhuman primates and humans. Evol Anthropol. 28 (4), 210-223. doi: 10.1002/evan.21793.

Pitulko, V., \& Kasparov, A. (2017). Archaeological dogs from the Early Holocene Zhokhov site in the Eastern Siberian Arctic. J. Archaeol. Sci., 13, 491-515. https://doi.org/10.1016/j.jasrep.2017.04.003.

Plavcan, J. M. (2012). Sexual size dimorphism, canine dimorphism, and male-male competition in primates: where do humans fit in? Hum Nat. 23(1), 45-67. doi: 10.1007/s12110-012-9130-3.

Pober, B. R. (2003). Williams Syndrome. In Kozel, B. A., Bayliss, S. J., Berk, D. R., Waxler, J. L., Knutsen, R. H., \& Danback, J. R (Eds.), NORD Guide to Rare Disorders (p. 270). Philadelphia, PA: Lippincott Williams \& Wilkins.

Pober, B. R. (2010). Williams-Beuren Syndrome. N. Engl. J. Med. 362, 239-252.

Pongrácz, P., Molnár, C., \& Miklósi, A. (2010). Barking in family dogs: an ethological approach. Vet. J., 183(2), 141-7. https://doi:10.1016/j.tvj1.2008.12.010. 
Pörtl, D., \& Jung, C. (2017). Is dog domestication due to epigenetic modulation in brain? Poster session presentation at the meeting of the Canine Science Forum, Padua, IT, in Dog Behav., 2(3), S1-S126. https://doi.org/10.4454/db.v2i3.

Pörtl, D., \& Jung, C. (2019). Physiological pathways to rapid prosocial evolution. Biol. Futura, 70(2), 93-102. https://doi.org/10.1556/019.70.2019.12.

Powell, L., Edwards, K. M., Michael, S., McGreevy, P., Bauman, A., Guastella, A. J., Drayton, B \& Stamatakis, E. (2020). Effects of human-dog interactions on salivary oxytocin concentrations and heart rate variability: A four-condition cross-over trial, Anthrozoös, 33, 37-52. https://DOI:10.1080/08927936.2020.1694310.

Prassack, K. A., DuBois, J., Láznicková-Galetová, M., Germonpré, M., \& Ungar, P. S. (2020). Dental microwear as a behavioral proxy for distinguishing between canids at the Upper Paleolithic (Gravettian) site of Predmostí, Czech Republic. J. Archaeol. Sci., 115, 105092. https://DOI:10.1016/j.jas.2020.105092.

Progovac, L., \& Benítez-Burraco, A. (2019). From physical aggression to verbal behavior: Language evolution and self-domestication feedback loop. Front Psychol 10, 2807 doi: 10.3389/fpsyg.2019.02807

Prothmann, A., Ettrich, C., \& Prothmann, S. (2009). Preference of, and responsiveness to people, dogs and objects in children with autism. Anthrozoös 22, 161-171. https://10.2752/175303709X434185. 
Range, F., and Virányi, Z. (2013). Social learning from humans or conspecifics: differences and similarities between wolves and dogs. Front. Psychol., 4, 868. https://doi:10.3389/fpsyg.2013.00868.

Range, F., Virányi, Z. (2011). Development of gaze following abilities in wolves (Canis lupus). PLoS One, 6(2), e16888. https://doi.org/10.1371/journal.pone.0016888

Rehkämper, G., Frahm, H. D., \& Cnotka, J. (2008). Mosaic evolution and adaptive brain component alteration under domestication seen on the background of evolutionary theory. Brain Behav. Evol., 71(2), 115-26. https://doi.org/10.1159/000111458

Rizzolatti, G., \& Craighero, L. (2004). The mirror-neuron system. Annu. Rev. Neurosci., 27, 169-192. https://doi.org/10.1146/annurev.neuro.27.070203.144230.

Russell, E. (2018). Greyhound Nation: A coevolutionary history of England, 1200-1900. Cambridge: Cambridge University Press.

Saetre, P., Lindberg, J. Leonard, J.A., Olsson, K., Pettersson, U., Ellegren, H., Bergström, T. F., Vilà, C., \& Jazin, E. (2004). From wild wolf to domestic dog: Gene expression changes in the brain. Mol. Brain Res., 126, 198-206.

Sams, N.J., Fortney, E.V., \& Willenbring, S. (2006). Occupational therapy incorporating animals for children with autism: a pilot investigation. Am J. Occup. Ther., 60, 268-274. https://doi.org/10.5014/ajot.60.3.268. 
Sánchez-Villagra, M. R., \& van Schaik, C. P. (2019). Evaluating the self-domestication hypothesis of human evolution. Evol. Anthropol. 28(3):133-143. doi: 10.1002/evan.21777.

Sánchez-Villagra, M. R., Geiger, M., \& Schneider, R. A. (2016): The taming of the neural crest: a developmental perspective on the origins of morphological covariation in domesticated mammals. R Soc Open Sci 3, 160107.

Sandler, W., Meir, I., Padden, C., \& Aronoff, M. (2005). The emergence of grammar: systematic structure in a new language. Proc Natl Acad Sci U S A. 102, 2661-2665.

Santana, M. D. R., Martiniano E. C., Monteiro, L. R. L., De Oliveira, M., Valenti, V. E., Garner, D. M., Vanderlei F., \& De Abreu, L. C. (2017). Cortisol levels and autonomic control of heart rate in healthy subjects. Acta Medica Mart., 17(2), 5-14. https://doi.org/10.1515/acm-2017-0006.

Schaschl, H., Huber, S., Schaefer, K., Windhager, S., Wallner, B., \& Fieder, M. (2015). Signatures of positive selection in the cis-regulatory sequences of the human oxytocin receptor (OXTR) and arginine vasopressin receptor 1a (AVPR1A) genes. BMC Evol. Biol., 15, 85. https://doi:10.1186/s12862-015-0372-7.

Schleidt, W. M., \& Shalter, M. D. (2003). Co-evolution of humans and canids: An alternative view of dog domestication: Homo Homini Lupus? Evol. Cogn., 9(1), 57-72. 
Schleidt, W. M., \& Shalter, M. D. (2018). Dogs and mankind: Coevolution on the move - an update. Human Ethol. Bull., 33(1), 15-38.

Schoenebeck, J. J., \& Ostrander, E. A. (2014). Insights into morphology and disease from the dog genome project. Ann. Rev. Cell Dev. Biol., 30, 535-560. https://doi:10.1146/annurev-cellbio-100913-012927.

Schwendler, R. H. (2012). Diversity in social organization across Magdalenian Western Europe ca. 17-12,000 BP. Quater. Int., 272, 333-353.

https://doi:10.1016/j.quaint.2012.03.054.

Sexton, C. L. (2019). Face to face: Impacts of expressive communication and domestication on eye muscle morphology. ProQuest Dissertations Publishing, 13880114.

https://search.proquest.com/openview/e71ef7139f42082696b6fcc924ef80a0/1.pdf?pqorigsite $=$ gscholar $\&$ cbl $=51922 \&$ diss $=y$. Accessed, 11 March 2020

Shea, B. (1989). Heterochrony in human evolution: the case for neoteny reconsidered. Am J. Phys. Anthropol. 32, 69e101.

Shearin, A. L., \& Ostrander, E. A. (2010). Canine morphology: hunting for genes and tracking mutations. PLoS Biol., 8(3), e1000310. https://doi.org/10.1371/journal.pbio.1000310. 
Shilton, D., Breski, M., Dor D., \& Jablonka, E. (2020). Human social evolution: Selfdomestication or self-control? Front. Psychol., 11, 134. https://doi:10.3389/fpsyg.2020.00134.

Shipman, P. (2015). How do you kill 86 mammoths? Taphonomic investigations of mammoth megasites. Quatern. Int., 359-360, 38-46.

Siewertsen, C., French, E., \& Teramoto, M. (2015). Autism spectrum disorder and pet therapy. Adv. Mind Body Med., 29(2), 22-5.

Sikora, M., Seguin-Orlando, A., Sousa, V. C., \& Albrechtsen, A. (2017). Ancient genomes show social and reproductive behavior of early Upper Paleolithic foragers. Science, 358(6363), 659-662. https://DOI:10.1126/science.aao1807.

Sinha, C. (2015). Language and other artifacts: socio-cultural dynamics of niche construction. Front. Psychol., 6, 1601. doi: 10.3389/fpsyg.2015.01601.

Somel, M., Franz, H., Yan, Z., Lorenc, A., Guo, S., Giger, T., Kelso, J., Nickel, B., Dannemann, M., Bahn, S., Webster, M. J., Weickert, C. S., Lachmann, M., Pääbo, S., \& Khaitovich, P. (2009) Transcriptional neoteny in the human brain. Proc Natl Acad Sci. U $S A 106,5743-5748$.

Stahler, D., Heinrich, B., \& Smith, D. (2002). Common ravens, Corvus corax, preferentially associate with grey wolves, Canis lupus, as a foraging strategy in winter. Anim. Behav., 64(2), 283-290. https://doi.org/10.1006/anbe.2002.3047. 
Stringer, C. (2016). The origin and evolution of Homo sapiens. Philos Trans R Soc Lond B Biol Sci. 371, 20150237.

Takahasi, M,, \& Okanoya, K. (2010). Song learning in wild and domesticated strains of white-rumped munia, Lonchura striata, compared by cross-fostering procedures: domestication increases song variability by decreasing strain-specific bias. Ethology 116, 396-405.

Tang, R., Noh, H.J., Wang, D., \& Karlsson. E. K. (2014). Candidate genes and functional noncoding variants identified in a canine model of obsessive-compulsive disorder. Genome Biol., 15, 25. https://doi.org/10.1186/gb-2014-15-3-r25.

Thakur, D., Martens, M. A., Smith, D. S., \& Roth, E. (2018). Williams Syndrome and music: A systematic integrative review. Front. Psychol., 9, 2203. https://doi:10.3389/fpsyg.2018.02203.

Thalmann, O., Shapiro, B., Cui, P., Schuenemann, V. J., Sawyer, S. K., Greenfield, D. L., Germonpré, M. B., Sablin, M. V., López-Giráldez, F., Domingo-Roura, X., Napierala, H., Uerpmann, H. P., Loponte, D. M., Acosta, A. A., Giemsch, L., Schmitz, R. W., Worthington, B., Buikstra, J. E., Druzhkova, A., Graphodatsky, A. S., ... Wayne, R. K. (2013). Complete mitochondrial genomes of ancient canids suggest a European origin of domestic dogs. Science, 342(6160), 871-874. https://10.1126/science.1243650 
Theofanopoulou, C., Gastaldon, S., O’Rourke, T., Samuels, B.D., Messner, A., Martins, P.T., Delogu, F., Alamri, S., \& Boeckx, C. (2017). Self-domestication in Homo sapiens: Insights from comparative genomics. PLoS ONE 12, e0185306.

Thomas, J. (2014). Self-domestication and Language Evolution. PhD thesis, University of Edinburgh.

Thomas, J., \& Kirby, S. (2018). Self domestication and the evolution of language. Biol. Philos. 33(1), 9. doi: 10.1007/s 10539-018-9612-8

Topál, J., Gergely, G., Erdőhegyi, Á., Csibra G., \& Miklósi Á. (2019). Differential sensitivity to human communication in dogs, wolves, and human Infants. Science, 325(5945), 1269-1272. https://DOI:10.1126/science.1176960.

Udell, M. A. (2015). When dogs look back: inhibition of independent problem-solving behaviour in domestic dogs (Canis lupus familiaris) compared with wolves (Canis lupus). Biol. Lett. 11, 20150489.

Valiyamattam, G. J., Katti, H., Chaganti, V., O’Haire, M., \& Sachdeva, V. (2019). Do animals engage greater social attention in autism? An eye tracking analysis. Poster session presentation at the meeting of the International Society for Anthrozoology, Orlando, USA.

van Bokhoven, I., Van Goozen, S. H., van Engeland, H., Schaal, B., Arseneault, L., Seguin, J. R., Nagin, D. S., Vitaro F., \& Tremblay, R. E. (2005). Salivary cortisol and 
aggression in a population-based longitudinal study of adolescent males. J. Neural Transm., 112, 1083-1096.

Vanhaeren, M. \& d'Errico, F., (2006). Aurignacian ethno-linguistic geography of Europe revealed by personal ornaments. J. Archaeol. Sci., 33, 1105-1128.

Venkataraman, V. V., Kerby, J. T., Nguyen, N., Ashenafi, Z. T., \& Fashing, P. J. (2015). Solitary Ethiopian wolves increase predation success on rodents when among grazing gelada monkey herds. J. Mammal., 96(1), 129-137. https://DOI:10.1093/jmammal/gyu013.

Vermeire, S., Audenaert, K., De Meester, R., Vandermeulen, E., Waelbers, T., De Spiegeleer, B., et al., (2012). Serotonin 2A receptor, serotonin transporter and dopamine transporter alterations in dogs with compulsive behaviour as a promising model for human obsessive-compulsive disorder. Psychiatry Res., 201(1), 78-87.

Viau, R., Arsenault-Lapierre, G., Fecteau, S., Champagne, N., Walker, C.-D., \& Lupien, S. (2010). Effect of service dogs on salivary cortisol secretion in autistic children. Psychoneuroendocrinology, 35(8), 1187.

Villalta-Gil, V., Roca, M., Gonzalez, N., Domenec, E., Cuca, B., Escanilla, A., \& Haro, J. M. (2009). Dog-assisted therapy in the treatment of chronic schizophrenia inpatients. Anthrozoos, 22, 149-159. https://10.2752/175303709X434176. 
vonHoldt, B. M., Ji, S. S., Aardema, M. L., Stahler, D. R., Udell, M., \& Sinsheimer, J. S. (2018). Activity of Genes with functions in human Williams-Beuren Syndrome is impacted by mobile element insertions in the gray wolf genome. Genome Biol. Evol, 1,10(6), 1546-1553. https://doi:10.1093/gbe/evy112.

vonHoldt, B. M., Ji S. S., Aardema M. L., Stahler D.R., Udell M. A. R., \& Sinsheimer J. S. (2020). Heritability of interpack aggression in a wild pedigreed population of North American grey wolves. Mol. Ecol. https://doi.org/10.1111/mec.15349.

vonHoldt, B. M., Pollinger, J. P., Lohmueller, K. E., Han, E., Parker, H. G., Quignon, P., \& Wayne, R. K. (2010). Genome-wide SNP and haplotype analyses reveal a rich history underlying dog domestication. Nature, 464(7290), 898-902. https://doi.org/10.1038/nature08837.

vonHoldt, B. M., Shuldiner, E., Koch, I., Kartzinel, R., Hogan, A., Brubaker, L., Wanser, S., Stahler, D., Wynne, C., Ostrander, E.A., Sinsheimer, J., \& Udell, M. (2017). Structural variants in genes associated with human Williams-Beuren syndrome underlie stereotypical hypersociability in domestic dogs. Sci. Adv., 3(7), e1700398. https://doi:10.1126/sciadv.1700398.

Wayne, R. (2013). Dogs likely originated in Europe more than 18,000 years ago. UCLA Biologists Report. Nov 14, 2013.

Welberg, L. (2018). Mirror neurons: Singing in the brain. Nat. Rev. Neurosci., 9, 163. https://doi.org/10.1038/nrn2340. 
Whitworth, J. A., Williamson, P. M., Mangos, G., \& Kelly, J. J. (2005). Cardiovascular consequences of cortisol excess. Vasc. Health Risk Manag., 1(4), 291-299. https://doi:10.2147/vhrm.2005.1.4.291.

Wijker, C., Leontjevas, R., Spek, A., \& Enders-Slegers, M.-J. (2019). Effects of dog assisted therapy for adults with autism spectrum disorder: An exploratory randomized controlled trial. J. Autism Dev. Disord. https://doi.org/10.1007/s10803-019-03971-9.

Wilkins, A. S., Wrangham, R. W., \& Fitch, W. T. (2014). The “domestication syndrome” in mammals: a unified explanation based on neural crest cell behavior and genetics. Genetics 197(3), 795-808. doi:10.1534/genetics.114.165423

Xu, X. H., Huang, X. W., Qun, L., Li, Y. N., Wang, Y., et al. (2014). Two functional loci in the promoter of EPAS1 gene involved in high-altitude adaptation of Tibetans. Sci. Rep., 12(4), 7465. https://doi:10.1038/srep07465.

Zanella, M., Vitriolo, A., Andirko, A., Martins, P. T., Sturm, S., O'Rourke, T., Laugsch, M., Malerba, N., Skaros, A., Trattaro, S., Germain, P. L., Mihailovic, M., Merla, G., Rada-Iglesias, A., Boeckx, C., \& Testa, G. (2019) Dosage analysis of the 7q11.23 Williams region identifies BAZ1B as a major human gene patterning the modern human face and underlying self-domestication. Sci $A d v$. 5(12), eaaw7908. doi: 10.1126/sciadv.aaw7908. 
Zhang, H., Gross, J., De Dreu, C., \& Ma, Y. (2019). Oxytocin promotes coordinated out-group attack during intergroup conflict in humans. Elife, 25(8), 40698. https://doi:10.7554/eLife.40698.

Zhang, Z., Khederzadeh, S., \& Li, Y. (2020). Deciphering the puzzles of dog domestication. Zool. Res., 1-8. https://doi:10.24272/j.issn.2095-8137.2020.002.

Zhou, H., Hu, S., Matveev, R., Yu, Q., Li, J., Khaitovich, P., Jin, L., Lachmann, M., Stoneking, M., Fu, Q., \& Tang, K. (2015). A chronological atlas of natural selection in the human genome during the past half-million years. BioRxiv doi: http://dx.doi.org/10.1101/018929

Zollikofer, C. P. E., \& Ponce de León, M. S. (2010). The evolution of hominin ontogenies. Semin. Cell. Dev. Biol. 21, 441-452. 